\title{
Рaper
}

OPEN ACCESS

\section{Mycoplasma hyopneumoniae vaccination at or shortly before weaning under field conditions: a randomised efficacy trial}

\author{
I. Arsenakis, A. Michiels, R. Del Pozo Sacristán, F. Boyen, F. Haesebrouck, D. Maes
}

\begin{abstract}
This study assessed the efficacy of two different Mycoplasma hyopneumoniae vaccination programmes in relation to the time of weaning. Eight hundred and twenty-eight piglets were randomly divided into three groups: group V1 was vaccinated three days before weaning, group V2 at weaning (21 days of age) and group NV was left non-vaccinated. Vaccinations were performed using Ingelvac MycofLEX. After the nursery period, 306 pigs were allocated to fattening unit (F1) and 501 pigs to a second unit (F2). Efficacy was evaluated using performance parameters and pneumonia lesions at slaughter. Statistically significant differences were obtained in $\mathrm{F} 2$ where group V1 had a higher average daily weight gain compared to groups V2 and NV for the entire study period (17 and $18 \mathrm{~g} / \mathrm{day}$, respectively) and the fattening period ( 26 and $36 \mathrm{~g} /$ day, respectively) $(P<0.05)$. Considering respiratory disease scores for both fattening units, group V1 was the only group where coughing severity did not increase significantly between placement and the end of the fattening period $(P>0.05)$. Between groups, there were no statistically significant differences for the average lung lesion scores $(V 1=3.44 ; V 2=4.61 ; N V=4.55, P>0.05)$ and the prevalence of pneumonia ( $(\mathrm{V} 1=35.0$ per cent; $\mathrm{V} 2=38.0$ per cent; $N V=41.4$ per cent, $P>0.05$ ). Overall, vaccination against $M$ hyopneumoniae before weaning provided numerically better performance than vaccination at weaning, but did not reach statistical significance. An influenza outbreak in $\mathrm{F} 1$ and the presence of coexisting mixed respiratory infections in both $F 1$ and $F 2$ could have possibly influenced the performance of both vaccinated groups across all measured parameters.
\end{abstract}

\section{Introduction}

Mycoplasma hyopneumoniae is the primary agent of enzootic pneumonia (EP) which affects mainly grow-finishing pigs and inflicts major economic losses on the pig industry (Thacker and Minion 2012). Vaccination is a very common control measure which has been extensively proven to reduce performance losses, the severity of clinical signs and lung lesions (Maes and others 1998, 1999, Jensen and others 2002, Wilson and others 2012, Del Pozo Sacristán and others 2014).

Currently, vaccination at weaning is commonly practised as the handling of the piglets is inevitable at that time (Alarcon

\section{Veterinary Record (2017)}

I. Arsenakis, DVM, MSc, MRCVS,

A. Michiels, DVM,

R. Del Pozo Sacristán, DVM, PhD,

MSc, DipECPHM,

D. Maes, DVM, PhD, MS, MSc,

DipECVPH, DipECPHM,

Unit Porcine Health Management, Department of Reproduction,

Obstetrics \& Herd Health, Faculty of Veterinary Medicine, Ghent University, Salisburylaan 133, Merelbeke 9820,

Belgium

F. Boyen, DVM, PhD, DipECPHM, doi: 10.1136/vг.104075

F. Haesebrouck, DVM, PhD, DipECPHM,

Department of Pathology, Bacteriology and Avian Diseases, Faculty of

Veterinary Medicine, Ghent University, Salisburylaan 133, Merelbeke 9820,

Belgium

E-mail for correspondence: loannis. Arsenakis@UGent.be

Provenance: Not commissioned; externally peer reviewed

Accepted April 23, 2017 and others 2014, Del Pozo Sacristán and others 2014). On the other hand, weaning is one of the most stressful events in the life of a piglet (Pié and others 2004, Campbell and others 2013). It is not recommended to vaccinate animals when they are severely stressed (Chase and others 2012). For that reason, vaccinating the animals two to three days before weaning is also practised by some pig producers (Gillespie and others 2010).

Consequently, one important question that remains unaddressed is whether vaccination at the day of weaning has an influence on the efficacy of $M$ hyopneumoniae vaccines. A previous study investigated the efficacy of a single $M$ hyopneumoniae vaccination three days before weaning or at weaning against experimental challenge infection with a virulent $M$ hyopneumoniae field strain (Arsenakis and others 2016). The results showed that the group that was vaccinated three days before weaning had the lowest macroscopic and histopathological lung lesions. A difference of three days between the two vaccination groups was chosen to allow the first and most critical steps of the immune response to develop before the stress of weaning (Kick and others 2011). However, significant differences between the vaccinated groups were only obtained for the histopathological lung lesions. Thus, it was considered that a field study would provide further insight on the same topic, since it would permit to include more animals, to test the effect under practical conditions with concurrent infections with other respiratory pathogens and to investigate performance data until slaughter age. 
The objective of this study was therefore to investigate the efficacy of a one-dose $M$ hyopneumoniae vaccination applied either at weaning or three days before weaning in a Belgian pig herd with mixed respiratory disease in the fattening period, where $M$ hyopneumoniae has been involved as an important pathogen. Average daily weight gain (ADG) and the severity of Mycoplasma-like pneumonia lesions at slaughter constituted the primary efficacy parameters.

\section{Materials and methods Herd description}

The study was conducted between September 2013 and March 2014 in a two-site Belgian pig herd, operating a four-week batch production system for the sows (Table 1). At three weeks of age, the piglets were weaned and transferred to the nursery unit located on the same site. The nursery unit consisted of six compartments with 20 pens per compartment (20 pigs per pen). Each compartment had fully slatted floors, channel ventilation and a stocking density of $0.27 \mathrm{~m}^{2} /$ pig. At 10 weeks of age, approximately 30 per cent of the pigs were sold, while the remaining ones were allocated to two different fattening units, in which they were kept until slaughter (27 weeks of age). The first fattening unit (F1) was within-site and consisted of three compartments of 26 pens each (13 pigs per pen). The second fattening unit (F2) was located $5 \mathrm{~km}$ from the sow herd and consisted of five compartments of six pens each (13 pigs per pen) and of two compartments of four pens each (14 pigs per pen). Both F1 and F2 had fully slatted floors, conventional mechanical ventilation systems (combining vent doors and ceiling fans) and a stocking density of $0.75 \mathrm{~m}^{2} / \mathrm{pig}$.

One month before the onset of the study, tracheobronchial swabs (TBS) were collected from 10-week, 16-week and 24-week-old pigs (10 for each age group) and the results showed that $7 / 10,5 / 10$ and $10 / 10$ pigs, respectively, were positive for $M$ hyopneumoniae by nested PCR (nPCR; Stärk and others 1998). Blood samples were obtained from 24-week-old pigs, and 9/10 were serologically positive for $M$ hyopneumoniae (sample to positive $(\mathrm{S} / \mathrm{P})$ values higher than 0.4$)$ using an indirect ELISA (HerdCheck $M$ hyo, IDEXX). One hundred of those fattening pigs were examined at the slaughterhouse, and Mycoplasma-like lung lesions were present on 51 per cent of the lungs. Before the initiation of the study, the herd did not perform any vaccination of the fattening pigs, apart from the one against boar taint (Improvac, Zoetis)

\section{TABLE 1: Herd description and health management practices}

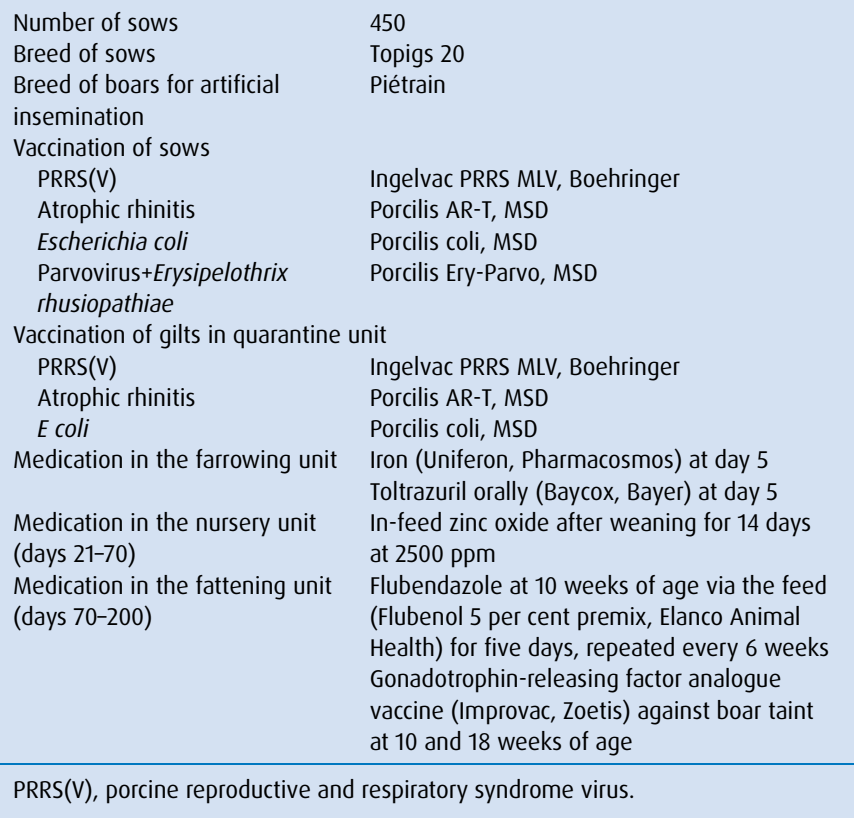

\section{Study population and experimental design}

In total, 828 pigs originating from one batch of sows were selected for this study. These pigs were offspring from 69 randomly selected sows. The parity distribution of the selected sows was from $1(n=15)$ to $13(n=1)$, with an average \pm sd of 2.6 \pm 1.8 parity number. Parity 2 sows constituted the largest group $(n=34)$. At 14 days of age, the pigs were individually ear-tagged and randomly allocated to one of the three treatment groups. Within each litter, an equal number of pigs $(n=4)$ was allocated to each treatment group (blocked randomisation). This experimental design was followed so that there is no difference between treatment groups in the average parity number of the sows providing the piglets. By that way, confounding factors that might influence the results could be minimised. All allocations were performed by the third author. Finally, each treatment group consisted of 276 pigs.

The three treatment groups were: V1 (vaccinated before weaning at 18 days of age), V2 (vaccinated at the day of weaning, at 21 days of age, one to three hours before the separation from the sow) and a non-vaccinated (NV) group. Pigs in groups V1 and V2 received a single-dose intramuscular injection $(1 \mathrm{ml})$ of a commercial $M$ hyopneumoniae bacterin vaccine (Ingelvac MycoFLEX, Boehringer Ingelheim).

In the nursery unit, piglets from maximum three different litters were regrouped according to weight and sex, while upon transfer to the fattening units, the pigs from maximum two different nursery pens were regrouped according to pen size and sex. Animals housed within the same pen in the nursery and fattening units belonged to the same treatment group. Within the nursery and fattening units, the different treatment groups were allocated alternately between the pens, until each compartment was full. In the nursery unit, only two out of the six available compartments were filled with animals included in the trial. In F1, only one compartment was used, whereas in F2, all compartments were used. During the entire trial, water and commercial feed (meal) were supplied ad libitum to the pigs. Feed (commercial meal), housing, management factors, sex distribution and prophylactic treatment were the same for the three groups. The study was approved by the ethical committee for animal experiments of the Faculty of Veterinary Medicine, Ghent University (EC2013/171).

\section{Parameters of comparison}

\section{Performance parameters}

In order to obtain the $\mathrm{ADG}$ (g/pig/day), all pigs were individually weighed at two weeks of age, at the end of the nursery period (10 weeks of age) and before slaughter (27 weeks of age). Weighing was performed in a blinded manner with respect to the treatment status by first and second authors and animal caretakers.

\section{Clinical parameters}

Coughing severity was measured blindly by the first author every two weeks, starting from the beginning of the fattening period. All measurements throughout the fattening period were obtained following the same pen order, each time starting at 8:00, first from F1 and then directly moving to F2. The number of pigs coughing per pen was counted for 10 minutes. Then, a respiratory disease score (RDS) was calculated by dividing the number of pigs per pen that coughed during 10 minutes by the total number of pigs in that pen, multiplied by 100 (Mateusen and others 2002, Del Pozo Sacristán and others 2012).

In case of respiratory or neurological signs, only treatment with amoxicillin by intramuscular injection or via the drinking water was allowed. Possible respiratory disease problems were monitored by paired sera from 10 coughing pigs, obtained during the outbreak and three weeks later (referred to as pre-serum and post-serum samples, respectively). The sera were analysed to detect antibodies against porcine reproductive and respiratory syndrome virus (PRRS(V)) (HerdCheck PRRS ELISA, IDEXX), porcine circovirus type 2 (PCV-2) (IgM and IgG, Ingezim PCV2 
ELISA, Ingenasa), swine influenza virus (SIV) (H1N1, H1N2, H3N2, standard haemagglutination inhibition test), $M$ hyopneumoniae (HerdCheck $M$ hyo, IDEXX), Haemophilus parasuis (Hps OppA, Biocheck) and Actinobacillus pleuropneumoniae (serotypes 1, 9 or 11 and serotype 2; Swinecheck APP 1,9,11 and Swinecheck APP 2, Biovet). Additionally, paired nasal swabs from the same animals were collected to monitor SIV by a realtime reverse transcription PCR (rRT-PCR; VetMAX-Gold SIV Detection Kit, Life technologies) detecting type A SIV-specific RNA (Bowman and others 2016).

Postmortem examination was performed on a subset of dead pigs in order to assess the possible cause of death. In all cases, postmortem examinations were combined with bacteriological culture, antimicrobial susceptibility testing and histopathology.

\section{Serological examination}

Blood samples were collected from the same 20 randomly selected pigs per group at 2, 10, 18 and 26 weeks of age to measure antibodies against $M$ hyopneumoniae, using a blocking ELISA (infectious disease enzyme immunoassay, $M$ hyopneumoniae enzyme immunoassay Kit, Oxoid, UK) as previously done by Del Pozo Sacristán and others (2014). In each treatment group, equal numbers of sampled pigs were distributed across fattening units. Inhibition percentages (IP) for all sera were also calculated considering the optical density (OD) value of each serum sample as well as the negative control according to Sibila and others (2004). Classification of individual sera on the basis of IP values was as follows: IP $<30$ per cent, negative; IP $>50$ per cent, positive; IP $\geq 30$ per cent and $\leq 50$ per cent, equivocal.

Thirty blood samples (five for each group/fattening unit) were randomly selected from the blood samples collected at 26 weeks of age. These were additionally tested for the presence of antibodies to PRRS(V), PCV-2, SIV, $H$ parasuis and A pleuropneumoniae. The serological tests used were the same as the ones used to investigate respiratory disease diagnostics (see Clinical parameters section).

\section{Detection of $M$ hyopneumoniae using QPCR on TBS}

TBS were collected from 20 pigs per group at 10, 14 and 18 weeks of age (the same 20 pigs from which blood samples were collected). Sampled pigs were endotracheally intubated with a sterile, semirigid canine urinary catheter, as described by Vangroenweghe and others (2015). All samples were immediately cooled at $4^{\circ} \mathrm{C}$ and stored at $-20^{\circ} \mathrm{C}$ until analysis. The material collected by TBS was used to quantify $M$ hyopneumoniae organisms by quantitative PCR (qPCR) as previously described by Marois and others (2010) and Del Pozo Sacristán and others (2012).

\section{Lung lesions}

The prevalence of Mycoplasma-like pneumonia lesions, fissures and pleurisy were recorded at slaughter via a blinded manner from the second author with the assistance of the first author. The total area (percentage) of macroscopically visible Mycoplasma-like lung lesions (lung lesion score) was quantified according to the scoring system described by Morrison and others (1985a) and Del Pozo Sacristán and others (2012, 2014). Mycoplasma-like pneumonia lesions (catarrhal bronchopneumonia (CBPn)) were defined as red-purplish areas of cranioventral consolidation raised above the surface or at the surface of each lobe and with a liver-like consistency (Holyoake and Callinan 2006, Del Pozo Sacristán and others 2012, 2014). Chronic Mycoplasma-like pneumonia lesions (fissures) were grey to purplish cranioventral scars, shrunken below the surface of the lobes, and had a more solid texture than the unaffected neighbouring parenchyma (Sorensen and others 2006, Del Pozo Sacristán and others 2012, 2014). Pleurisy was evident as fibrous adhesions between the lung lobes and/or the lungs and thoracic wall (Del Pozo Sacristán and others 2012, 2014, Michiels and others 2015).

\section{Statistical analysis}

The number of animals in each treatment group (276) allowed to assess a difference of $19 \mathrm{~g}(\mathrm{sd}=80)$ in $\mathrm{ADG}$ and 3.2 points $(\mathrm{sd}=13)$ in lung lesion score with 95 per cent certainty and 80 per cent statistical power (Win Episcope 2.0, Edinburgh, UK). The ADG and lung lesion score were the primary outcome parameters. Analysis of variance (ANOVA) was used to analyse bodyweights, ADG and RDS with treatment, compartment and sex included as fixed factor and pen as a random variable. In the combined model (including both fattening units), unit was additionally included as a random variable. Pairwise comparisons between the different treatment groups were made using Scheffe's test. Data that did not fulfil the criteria of normality and homogeneity of variances (lung lesion scores, qPCR values and serology IP) were analysed using non-parametric Kruskal-Wallis ANOVA. RDS and qPCR (time and group effect) data were analysed using repeated measures ANOVA. The average RDS summarised until 20 weeks of age and between 20 and 26 weeks of age were compared within each group using paired t-tests. Mortality rate, the percentage of pigs showing Mycoplasma-like lesions, fissures and pleurisy, the percentage of pigs showing $M$ hyopneumoniae antibodies and the percentage positive on qPCR were analysed using logistic regression with treatment and fattening unit as predictors for the model. Statistical results were considered significant when $P$ values were $\leq 0.05$ (two-sided test). The statistical package SPSS V.21.0 was used to analyse the data.

\section{Results \\ Performance parameters}

No statistically significant differences for the average bodyweight were shown between groups at inclusion in the study ( 2 weeks of age) $(\mathrm{P}=0.919)$, end of the nursery period (10 weeks of age) $(\mathrm{P}=0.109)$ and before slaughter (at 27 weeks of age, taking into account both fattening units) $(\mathrm{P}=0.263)$ (Table 2). When taking into account each fattening unit separately (Table 3), significant differences between groups for weight gains and ADG were observed only in F2. More specifically, group V1 had significantly higher weight gains and ADG when compared with groups V2 and NV.

\section{Clinical parameters}

There was a significant difference between F1 and F2 in the overall average RDS (no group effect) between 20 and 26 weeks of age $(\mathrm{P}=0.011)$. Coughing severity increased towards the end of the fattening period (between 20 and 26 weeks of age) (Table 4). Taking into account the average of both fattening units, the paired t-test results revealed significant differences between the two fattening periods in groups $\mathrm{NV}$ and $\mathrm{V} 2$ $(\mathrm{P}=0.031$ and $\mathrm{P}=0.007$, respectively), but not in group $\mathrm{V} 1$ $(\mathrm{P}=0.194)$.

During both fattening periods from 10 to 20 and from 20 to 26 weeks of age, higher average RDS were observed in F1 compared with F2 (Table 4). The coughing severity in F1 increased at approximately 20 weeks of age among all groups (Fig 1). For that reason, all pigs in F1 were medicated for a five-day period with amoxicillin via the drinking water. Paired sera from F1 showed that $8 / 10$ pigs had a positive post-serum titre (higher than 80 ) for the H3N2 subtype of SIV, with an average of 152. All pre-serum samples had a titre of 20. Moreover, all nasal swabs $(10 / 10)$ collected at the same time as the pre-serum were positive for SIV type A. Serology for $M$ hyopneumoniae showed an average $\mathrm{S} / \mathrm{P}$ ratio of 0.81 for the pre-serum ( $9 / 10$ pigs positive) and an average $S / P$ ratio of 1.02 for the post-serum ( $9 / 10$ pigs positive). Additional serology on pre-serum and post-serum samples showed that at both collection points 10/10 animals were positive for PRRS(V). Also, $10 / 10$ pigs and $1 / 10$ pigs were tested PCV-2 IgG and PCV-2 IgM positive, respectively.

Approximately three weeks after the occurrence of respiratory problems in F1, sporadic non-productive coughing was also 


\begin{tabular}{|c|c|c|c|c|c|}
\hline Performance parameters" & Age $(w)$ & $\begin{array}{l}\text { V1 } \\
n=270\end{array}$ & $\begin{array}{l}\text { V2 } \\
n=266\end{array}$ & $\begin{array}{l}\mathrm{NV} \\
\mathrm{n}=271\end{array}$ & P value \\
\hline \multirow[t]{3}{*}{ Average bodyweight (kg) } & 2 & $4.28 \pm 0.78$ & $4.32 \pm 0.77$ & $4.31 \pm 0.76$ & 0.919 \\
\hline & 10 & $23.56 \pm 3.76$ & $23.99 \pm 3.71$ & $24.28 \pm 3.90$ & 0.109 \\
\hline & 27 & $106.81 \pm 12.96$ & $105.21 \pm 13.88$ & $104.12 \pm 15.17$ & 0.263 \\
\hline \multirow[t]{2}{*}{ Weight gain (kg) } & $10-27$ & $83.26 \pm 11.44$ & $81.46 \pm 12.41$ & $80.10 \pm 13.42$ & 0.094 \\
\hline & $2-27$ & $102.55 \pm 12.76$ & $100.95 \pm 13.68$ & $99.71 \pm 14.90$ & 0.164 \\
\hline \multirow[t]{3}{*}{ ADG (g/pig/day) } & $2-10$ & $371 \pm 64$ & $376 \pm 69$ & $384 \pm 67$ & 0.076 \\
\hline & $10-27$ & $718 \pm 98$ & $701 \pm 108$ & $688 \pm 116$ & 0.094 \\
\hline & $2-27$ & $610 \pm 76$ & $600 \pm 81$ & $593 \pm 88$ & 0.164 \\
\hline Lung lesions & & $\mathrm{n}=134$ & $n=128$ & $\mathrm{n}=129$ & \\
\hline Prevalence of Mhyo-like lesions & Market & 35.0 & 38.0 & 41.4 & 0.602 \\
\hline Prevalence of fissures & Market & 37.5 & 38.7 & 39.7 & 0.943 \\
\hline Prevalence of pleurisy & Market & 7.2 & 9.6 & 12.5 & 0.381 \\
\hline Lung lesion score & Market & $3.44 \pm 6.77$ & $4.61 \pm 11.11$ & $4.55 \pm 9.99$ & 0.617 \\
\hline Lung lesion score (min-max) & Market & $0-32$ & $0-64$ & $0-66$ & \\
\hline
\end{tabular}

Treatment groups: V1 (vaccinated before weaning at 18 days of age), V2 (vaccinated on the day of weaning at 21 days of age) and NV (non-vaccinated group). Differences between groups were not statistically significant $(P>0.05)$

"Average daily weight gain (ADG)

\begin{tabular}{|c|c|c|c|c|c|c|c|c|c|}
\hline \multirow[b]{2}{*}{ Performance parameters" } & \multirow[b]{2}{*}{ Age (w) } & \multicolumn{4}{|l|}{ (F1) } & \multicolumn{4}{|l|}{$(\mathrm{F} 2)$} \\
\hline & & $\begin{array}{l}\mathrm{V} 1 \\
\mathrm{n}=101\end{array}$ & $\begin{array}{l}\mathrm{V} 2 \\
\mathrm{n}=102\end{array}$ & $\begin{array}{l}N V \\
n=103\end{array}$ & $P$ value & $\begin{array}{l}\mathrm{V} 1 \\
\mathrm{n}=169\end{array}$ & $\begin{array}{l}\text { V2 } \\
n=164\end{array}$ & $\begin{array}{l}\mathrm{NV} \\
\mathrm{n}=168\end{array}$ & $P$ value \\
\hline Average bodyweight (kg) & 27 & $98.43 \pm 11.20$ & $100.10 \pm 14.05$ & $98.20 \pm 13.16$ & 0.152 & $111.03 \pm 11.70$ & $108.13 \pm 13.00$ & $108.17 \pm 15.16$ & 0.065 \\
\hline \multirow[t]{2}{*}{ Weight gain $(\mathrm{kg})$} & $10-27$ & $76.12 \pm 9.30$ & $77.15 \pm 12.48$ & $75.25 \pm 11.64$ & 0.124 & $86.80 \pm 10.74^{\mathrm{A}}$ & $83.96 \pm 11.69^{B}$ & $83.25 \pm 13.60^{\mathrm{B}}$ & 0.011 \\
\hline & $2-27$ & $94.33 \pm 10.98$ & $95.91 \pm 13.90$ & $93.99 \pm 12.94$ & 0.124 & $106.68 \pm 11.55^{\mathrm{A}}$ & $103.81 \pm 12.73^{B}$ & $103.65 \pm 14.92^{B}$ & 0.038 \\
\hline \multirow[t]{2}{*}{ ADG (g/pig/day) } & $10-27$ & $656 \pm 81$ & $665 \pm 109$ & $648 \pm 100$ & 0.124 & $748 \pm 92^{\mathrm{A}}$ & $722 \pm 101^{B}$ & $712 \pm 117^{\mathrm{B}}$ & 0.010 \\
\hline & $2-27$ & $562 \pm 65$ & $570 \pm 82$ & $559 \pm 77$ & 0.139 & $634 \pm 68^{A}$ & $617 \pm 76^{B}$ & $616 \pm 88^{B}$ & 0.034 \\
\hline Lung lesions & & $\mathrm{n}=39$ & $n=37$ & $\mathrm{n}=39$ & & $\mathrm{n}=95$ & $\mathrm{n}=91$ & $\mathrm{n}=90$ & \\
\hline Prevalence of Mhyo-like lesions & Market & 32.4 & 41.0 & 48.7 & 0.357 & 36.1 & 36.9 & 37.6 & 0.980 \\
\hline Prevalence of fissures & Market & 51.3 & 43.6 & 48.7 & 0.788 & 31.3 & 36.9 & 35.0 & 0.727 \\
\hline Prevalence of pleurisy & Market & 7.5 & 14.6 & 15.0 & 0.529 & 7.0 & 7.6 & 11.2 & 0.579 \\
\hline Lung lesion score & Market & $3.68 \pm 7.57$ & $4.88 \pm 11.79$ & $3.56 \pm 5.93$ & 0.628 & $3.33 \pm 6.43$ & $4.50 \pm 10.88$ & $5.04 \pm 11.51$ & 0.844 \\
\hline Lung lesion score (min-max) & Market & $0-32$ & $0-64$ & $0-21$ & & $0-27$ & $0-60$ & $0-66$ & \\
\hline
\end{tabular}

Treatment groups: $\mathrm{V} 1$ (vaccinated before weaning at 18 days of age), V2 (vaccinated on the day of weaning at 21 days of age) and NV (nonvaccinated group). Within a row, different superscript letters indicate significant differences between values $(P<0.05)$.

"Average daily gain $(\mathrm{ADG})$.

observed in F2, mainly in group NV (Fig 1). A similar five-day treatment with amoxicillin via the drinking water was used. The serological test for $M$ hyopneumoniae showed an average S/P ratio of 0.79 for the pre-serum (7/10 pigs positive) and an average $\mathrm{S} / \mathrm{P}$ ratio of 1.08 for the post-serum ( $9 / 10$ pigs positive). Moreover, all pre-sera and post-sera were positive for $\operatorname{PRRS}(\mathrm{V})$ and anti-PCV-2 IgG antibodies.

The numbers of dead pigs in different treatment groups are presented in Table 5. In total, 55 pigs died during the entire study period. Postmortem examination was performed on a subset of dead animals (17/55): five from the nursery and six each for F1 and F2. All pigs that underwent postmortem examination and died during the nursery period had pathological signs of fibrinopurulent pericarditis and endocarditis. Streptococcus suis was isolated from the heart and kidneys. The pigs that died during the fattening period showed either pathological signs of respiratory or/and wasting disease characterised by pleurisy, pericarditis and/or purulent peritonitis. Several bacteria were isolated from the lungs of those pigs: Trueperella pyogenes (7/12), Pasteurella multocida (4/12) and $S$ suis (6/12). The main pathogen isolated from the pigs with pericarditis/purulent peritonitis was $S$ suis.

\section{Serological examination}

The serological results for $M$ hyopneumoniae at 2, 10, 18 and 26 weeks of age are presented in Table 6 . Regarding the average IP values from both units, at 10, 18 and 26 weeks of age, the vaccinated groups $\mathrm{V} 1$ and $\mathrm{V} 2$ exhibited higher average values when compared with $\mathrm{NV}(\mathrm{P}=0.004, \mathrm{P}=0.066$ and $\mathrm{P}=0.159$, respectively).

The serological examination for the other pathogens revealed that in F1, at 26 weeks of age, 8/15 pigs were seropositive for the H3N2 subtype of SIV, 15/15 pigs were seropositive for PRRS(V) and that $15 / 15$ and $6 / 15$ pigs were tested PCV-2 IgG and PCV-2 IgM positive, respectively. In $\mathrm{F} 2,0 / 15$ pigs were seropositive for the H3N2 subtype of SIV, 15/15 pigs were seropositive for PRRS (V), while $15 / 15$ and $10 / 15$ pigs were tested PCV-2 IgG and PCV-2 IgM positive, respectively.

\section{Detection of $M$ hyopneumoniae using qPCR on TBS}

Group V1 had significantly lower numbers of positive animals compared with groups V2 and NV at 10 and 14 (both fattening units) weeks of age $(\mathrm{P}=0.000$ and $\mathrm{P}=0.041$, respectively, Table 7). The average qPCR values of $M$ hyopneumoniae organisms were lower in group V1 than in groups V2 and NV, across 
TABLE 4: The average $( \pm s d)$ respiratory disease score (RDS) of the pigs between 10 and 20 weeks of age and between 20 and 26 weeks $(w)$ of age. Average values $( \pm s d)$ were calculated taking into account both and each fattening unit ( $F 1$ and $F 2$ ) separately

\begin{tabular}{lllll} 
Age range $(\mathrm{w})$ & $\mathrm{V} 1$ & $\mathrm{~V} 2$ & $\mathrm{NV}$ & P value \\
\hline Average both units & $\mathrm{n}=270$ & $\mathrm{n}=266$ & $\mathrm{n}=271$ & \\
\hline $10-20$ & $1.76 \pm 1.90^{\mathrm{A}}$ & $1.55 \pm 1.94^{\mathrm{A}}$ & $1.77 \pm 1.78^{\mathrm{A}}$ & 0.989 \\
$20-26$ & $2.70 \pm 2.91^{\mathrm{A}}$ & $3.68 \pm 2.86^{\mathrm{B}}$ & $\begin{array}{l}3.94 \pm 3.81^{\mathrm{B}} \\
0.031\end{array}$ & 0.801 \\
$\mathrm{P}^{*}$ & 0.194 & 0.007 & 0.031 & \\
\hline (F1) & $\mathrm{n}=101$ & $\mathrm{n}=102$ & $\mathrm{n}=103$ & \\
\hline $10-20$ & $2.22 \pm 1.98$ & $2.58 \pm 2.25$ & $2.25 \pm 1.40$ & 0.937 \\
$20-26$ & $5.45 \pm 2.70$ & $5.43 \pm 2.65$ & $4.08 \pm 2.99$ & 0.633 \\
\hline (F2) & $\mathrm{n}=169$ & $\mathrm{n}=164$ & $\mathrm{n}=168$ & \\
\hline $10-20$ & $1.55 \pm 1.91$ & $1.03 \pm 1.63$ & $1.55 \pm 1.94$ & 0.725 \\
$20-26$ & $1.43 \pm 2.05$ & $2.80 \pm 2.64$ & $3.87 \pm 4.25$ & 0.256
\end{tabular}

Treatment groups: V1 (vaccinated before weaning at 18 days of age), V2 (vaccinated on the day of weaning at 21 days of age) and NV (non-vaccinated group). Within a column, different superscript letters correspond to within-group significant differences between the two fattening periods $(" P<0.05)$ (paired $t$-tests). The $P$ value column indicates that there were no significant differences between groups during the two different fattening periods $(P>0.05)$

all sampling points, apart from F1 at 18 weeks of age where group V1 had the second lowest qPCR value (2.03) when compared with groups V2 (1.78) and NV (2.28). Significant differences between groups were observed at 10, 14 and 18 (both fattening units) weeks of age $(\mathrm{P}=0.000, \mathrm{P}=0.000$ and $\mathrm{P}=0.039$, respectively) (Table 7 )

\section{Lung lesions}

Lung lesion evaluation at slaughter was performed on 391 pigs $(\mathrm{n}=134 \mathrm{~V} 1 ; \mathrm{n}=128 \mathrm{~V} 2 ; \mathrm{n}=129 \mathrm{NV})$. Some pigs could not be
TABLE 5: Number of dead pigs per group between 2 and 27 weeks (w) of age. The contribution of each fattening unit (F1 and F2) on the combined (both units) mortality rates between 10 and 27 weeks of age is presented separately. All mortality rates were calculated according to the total number of animals included in each treatment group at the beginning of the study $(n=276)$

\begin{tabular}{cllrl} 
Age range $(w)$ & V1 & V2 & NV & P value \\
\hline $2-10$ & $6 / 276(2.17)$ & $10 / 276(3.62)$ & $5 / 276(1.81)$ & 0.371 \\
$10-27$ (both units) & $9 / 276(3.26)$ & $10 / 276(3.62)$ & $15 / 276(5.43)$ & 0.260 \\
$2-27$ & $15 / 276(5.43)$ & $20 / 276(7.24)$ & $20 / 276(7.24)$ & 0.607 \\
\hline (F1) & & & \\
\hline $10-27$ & $3 / 276(1.09)$ & $5 / 276(1.81)$ & $10 / 276(3.62)$ & 0.150 \\
\hline (F2) & & & \\
\hline $10-27$ & $6 / 276(2.17)$ & $5 / 276(1.81)$ & $5 / 276(1.81)$ & 0.983
\end{tabular}

Treatment groups: V1 (vaccinated before weaning at 18 days of age), V2 (vaccinated on the day of weaning at 21 days of age) and NV (non-vaccinated group). The $P$ value column indicates that there were no significant differences between groups in mortality rates during the three different production periods $(P>0.05)$

evaluated because of lost ear tags and lungs that did not reach the examination stand. Taking into account both F1 and F2 (Table 2), no statistically significant differences were found between treatment groups across all measured parameters.

\section{Discussion}

The present field study investigated the efficacy of one-dose vaccination against $M$ hyopneumoniae, applied either three days before weaning (V1) or at the day of weaning (V2). The working hypothesis was that group V1 will perform better than group V2 across the different parameters investigated as the possible

\section{Respiratory disease score (RDS)}

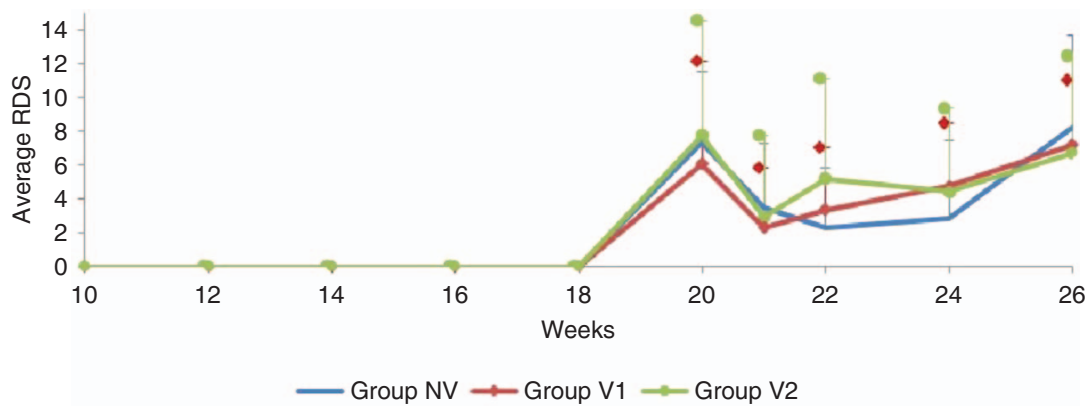

b

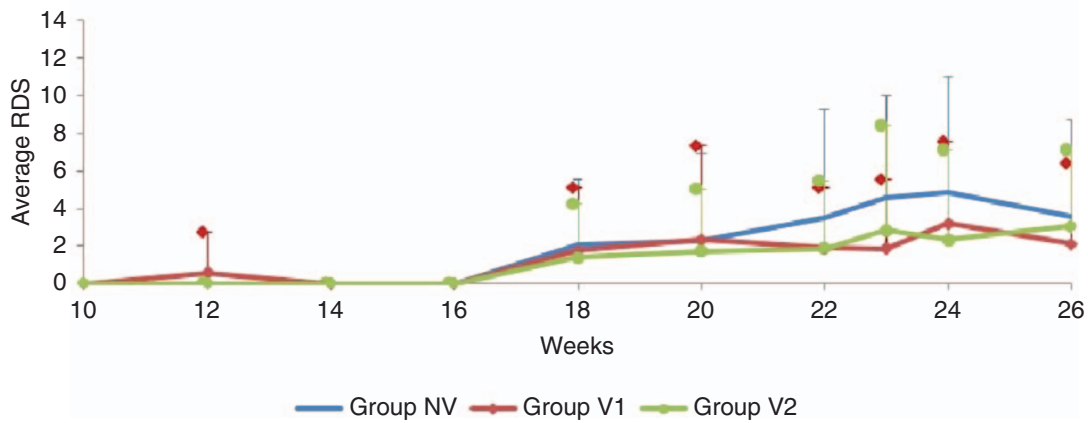

FIG. 1: Average respiratory disease score (RDS) over time in each of three groups of pigs per fattening unit (F1 and F2). Average RDS, together with the standard deviations (vertical bars), from 10 weeks of age until 26 weeks of age in group V1 (vaccinated before weaning at 18 days of age), V2 (vaccinated on the day of weaning at 21 days of age) and NV (non-vaccinated group). 


\begin{tabular}{|c|c|c|c|c|c|c|c|c|}
\hline \multirow[b]{2}{*}{ Age (w) } & \multicolumn{4}{|c|}{$\begin{array}{l}\text { Seropositive pigs for M. hyopneumoniae/ } \\
\text { total number of pigs sampled }\end{array}$} & \multicolumn{4}{|c|}{ Average IP values } \\
\hline & V1 & V2 & NV & $P$ value & V1 & V2 & NV & $P$ value \\
\hline 2 & $7 / 20$ & $10 / 20$ & $9 / 20$ & 0.624 & 44.2 & 42.6 & 45.6 & 0.929 \\
\hline 10 & $3 / 20$ & $0 / 20$ & $0 / 20$ & 1.000 & $49.9^{\mathrm{A}}$ & $43.4^{\mathrm{AB}}$ & $35.9^{\mathrm{B}}$ & 0.004 \\
\hline 18 (both units) & $5 / 20$ & $4 / 20$ & $3 / 20$ & 0.735 & 39.0 & 47.4 & 29.3 & 0.066 \\
\hline 26 (both units) & $18 / 20$ & $16 / 20$ & $16 / 20$ & 0.630 & 82.6 & 72.3 & 68.1 & 0.159 \\
\hline \multicolumn{9}{|l|}{ (F1) } \\
\hline 18 & $2 / 10$ & $2 / 10$ & $0 / 10$ & 0.980 & $33.4^{\mathrm{AB}}$ & $39.1^{\mathrm{B}}$ & $14.3^{\mathrm{A}}$ & 0.011 \\
\hline 26 & $9 / 10$ & $9 / 10$ & $7 / 10$ & 0.246 & $84.3^{\mathrm{A}}$ & $77.1^{\mathrm{B}}$ & $52.4^{B}$ & 0.006 \\
\hline \multicolumn{9}{|l|}{ (F2) } \\
\hline 18 & $3 / 10$ & $2 / 10$ & $3 / 10$ & 0.863 & 44.6 & 55.7 & 44.2 & 0.682 \\
\hline 26 & $9 / 10$ & $7 / 10$ & $9 / 10$ & 0.421 & 81.0 & 67.6 & 83.8 & 0.358 \\
\hline
\end{tabular}

Treatment groups: V1 (vaccinated before weaning at 18 days of age), V2 (vaccinated on the day of weaning at 21 days of age) and NV (nonvaccinated group). Within a row, different superscript letters correspond to significant differences in the average IP values between groups during the different sampling points $(P<0.05)$.

\begin{tabular}{|c|c|c|c|c|c|c|c|c|}
\hline \multirow[b]{2}{*}{ Age (w) } & \multicolumn{4}{|c|}{$\begin{array}{l}\text { QPCR positive pigs for M. hyopneumoniae / } \\
\text { total number of pigs sampled }\end{array}$} & \multicolumn{4}{|c|}{ Log Mhyo copies/ml } \\
\hline & V1 & V2 & NV & $P$ value & V1 & V2 & NV & $P$ value \\
\hline 10 & $0 / 20^{A}$ & $3 / 20^{B}$ & $17 / 20^{B C}$ & 0.000 & $0.58 \pm 0.71^{\mathrm{A}}$ & $0.96 \pm 0.75^{\mathrm{AB}}$ & $1.12 \pm 0.77^{c}$ & 0.000 \\
\hline 14 (both units) & $2 / 20^{A}$ & $7 / 20^{B}$ & $10 / 20^{B C}$ & 0.041 & $0.85 \pm 0.72^{\mathrm{A}}$ & $1.21 \pm 1.20^{\mathrm{BC}}$ & $1.76 \pm 1.59^{c}$ & 0.000 \\
\hline $\begin{array}{l}18 \text { (both units) } \\
\text { (F1) }\end{array}$ & $2 / 20$ & $8 / 20$ & $8 / 20$ & 0.088 & $1.99 \pm 2.45^{\mathrm{AB}}$ & $2.21 \pm 2.44^{\mathrm{AC}}$ & $2.19 \pm 2.35^{\mathrm{A}}$ & 0.039 \\
\hline 14 & $2 / 10$ & $2 / 10$ & $7 / 10$ & 0.073 & $0.91 \pm 0.25$ & $1.05 \pm 1.21$ & $1.62 \pm 1.38$ & 0.257 \\
\hline $\begin{array}{l}18 \\
(\mathrm{~F} 2)\end{array}$ & $1 / 10$ & $6 / 10$ & $4 / 10$ & 0.183 & $2.03 \pm 2.50$ & $1.78 \pm 2.03$ & $2.28 \pm 2.32$ & 0.076 \\
\hline 14 & $0 / 10$ & $5 / 10$ & $3 / 10$ & 0.613 & $0.78 \pm 1.18^{A}$ & $1.33 \pm 1.17^{\mathrm{AB}}$ & $1.86 \pm 1.69^{\mathrm{B}}$ & 0.001 \\
\hline 18 & $1 / 10$ & $2 / 10$ & $4 / 10$ & 0.205 & $1.96 \pm 2.42$ & $2.42 \pm 2.84$ & $2.07 \pm 2.37$ & 0.118 \\
\hline
\end{tabular}

Treatment groups: V1 (vaccinated before weaning at 18 days of age), V2 (vaccinated on the day of weaning at 21 days of age) and NV (non-vaccinated group). Within a row, different superscript letters indicate significant differences in the percentage of qPCR positive animals and qPCR values between groups during the different sampling points $(\mathrm{P}<0.05)$.

negative effect of weaning stress on vaccination would be decreased. Differences between group V1 and groups V2 and NV were mostly not statistically significant, except for the second fattening unit (F2) where group V1 had significantly higher weight gains and ADG when compared with groups V2 and NV between 10 and 27 weeks of age, as well as the whole study period. When taking into account both fattening units, group V1 had a numerically lower percentage of pigs with pneumonia, fissures and pleurisy at slaughter when compared with groups V2 and NV. The results of this study are in agreement with the previous experimental study of Arsenakis and others (2016) where group $\mathrm{V} 1$ performed better than V2 across all parameters concerning the assessment of lung lesions; however, differences between V1 and V2 were small and mostly statistically not significant.

In the present field study, serology and qPCR were both used to confirm the presence of pigs naturally infected with $M$ hyopneumoniae. At 26 weeks of age (1 week before slaughter), the percentage of tested pigs being seropositive for $M$ hyopneumoniae ranged between 70 and 90 per cent, while at 18 weeks of age, between 10 and 60 per cent of tested pigs were found to be qPCR positive. These results indicate that $M$ hyopneumoniae has been involved as an important respiratory pathogen in both fattening units. Martínez and others (2009) studied the relationship between infectious factors and pneumonia at slaughter on 39 fattening herds and confirmed that vaccination of piglets against $M$ hyopneumoniae did not appear to be related to the seroprevalences against the pathogen at slaughter. The qPCR results indicate that infection with $M$ hyopneumoniae started already during the nursery period, which may explain the high prevalence of pulmonary fissures at slaughter. Nevertheless, the diagnostic results show that apart from $M$ hyopneumoniae, there was a combination of viruses and other bacteria circulating in this herd.

In this study, it was decided to use the scoring system of Morrison and others (1985a), in order to quantify the severity of macroscopically visible Mycoplasma-like lung lesions. Those lesions are typically compatible with CBPn, which is the most common lung lesion associated with $M$ hyopneumoniae infection (Sorensen and others 2006, Meyns and others 2011). It is characterised by well-demarcated red-purplish areas that have a poor retraction state and thus, this scoring system was considered to be able to achieve the maximum possible differentiation against other types of lung lesions that are usually induced by viral pathogens, namely PRRS(V), SIV and PCV-2. Those pathogens most often cause interstitial pneumonia (IPn; Van Alstine 2012). The main difference between CBPn and IPn is that in the latter one, the lesions are widely distributed throughout the lungs and the lung lobes maintain their rubbery consistency (Van Alstine 2012, López and Martinson 2017). It is documented that $M$ hyopneumoniae predisposes to secondary pathogens such as $T$ pyogenes, $P$ multocida and $S$ suis (Goodwin and others 1965, Morrison and others 1985b, Ciprián and others 1988, Amass and others 1994, Opriessnig and others 2011, López and Martinson 2017). By that way, the lung lesions produced by $M$ hyopneumoniae are exacerbated, leading to 
more severe CBPn and pleural adhesions which extend the healing period (formation of fissures). Additionally, $M$ hyopneumoniae together with the aforementioned pathogens form the pathological complex of EP (Maes and others 1996, Thacker and Minion 2012). Vaccination against $M$ hyopneumoniae in herds facing severe $\mathrm{EP}$ has been shown to reduce the extent and severity of Mycoplasma-like lung lesions (Maes and others 1999, Alexopoulos and others 2004, Del Pozo Sacristán and others 2014).

In the current study, the percentage of pigs being positive for $M$ hyopneumoniae by qPCR increased between 14 and 18 weeks of age and the percentage of pigs seropositive for $M$ hyopneumoniae increased between 18 and 26 weeks of age. Additionally, in both F1 and F2, the RDS increased between 20 and 26 weeks of age when compared with the period between 10 and 20 weeks of age. This increase in the RDS occurred almost simultaneously with the increase in the percentage of $M$ hyopneumoniae seropositive animals towards the end of the fattening period. Nathues and others (2012), who examined the value of clinical examination in diagnosing EP in fattening pigs from 59 herds at 18 weeks of age, suggested that a combination of an increasing RDS towards the end of the fattening period together with a seroprevalence of more than 50 per cent against $M$ hyopneumoniae is highly indicative of an EP diagnosis. In the current study, the EP diagnosis is also justified by the detection of secondary pathogens, such as $T$ pyogenes, $P$ multocida and $S$ suis, in the pigs that underwent postmortem examination during the fattening period. The average percentage of Mycoplasma-like pneumonia lesions, in both F1 and F2, was considerably higher (38 per cent) than the average of 24 per cent reported by Meyns and others (2011), who collected data from 50 randomly selected batches from 60 Belgian herds at slaughter.

Of course, it is important to mention that viral pathogens, such as PRRS(V), SIV and PCV-2, were present in both fattening units (as documented by the diagnostics performed). The presence of such coinfections confirms the multifactorial nature of porcine respiratory disease complex (PRDC) in the present herd and could probably explain why in most of the measured parameters the vaccinated groups V1 and V2 did not perform significantly better than the NV group. The high percentage of Mycoplasma-like pneumonia lesions among all groups can likely be the result of interactions between $M$ hyopneumoniae and the viral (PRRS(V), SIV and PCV-2)) pathogens observed. All tested pigs were seropositive for PRRS(V) and PCV-2 IgG at 20, 23 and 26 weeks of age, and additionally a high number of pigs were seropositive for PCV-2 IgM at 26 weeks of age. Given that all pigs participating in this trial did not receive any other vaccination apart from the one with the commercial $M$ hyopneumoniae bacterin, these results prove that the herd was facing a chronic PRRS(V) infection in combination with a circulating PCV-2 infection at the nursery and fattening units.

It is generally acknowledged that most PRRS(V) and PCV-2 infections occurring at the end of the fattening period are subclinical and thus, this is the reason why in many cases no gross IPn lesions are detected at slaughter (Segalés and others 2012, Pileri and Mateu 2016). Nevertheless, the potentiating effect of the combination of viral pathogens with a $M$ hyopneumoniae infection on the severity of Mycoplasma-like lung lesions induced has already been experimentally described by Thacker and others (1999, 2001), Opriessnig and others (2004) and Dorr and others (2007), and demonstrated under field conditions by Del Pozo Sacristán and others (2014). It is possible that in this study a better control of viral pathogens such as PRRS(V), PCV-2 and SIV through better biosecurity and vaccination at an early age would allow vaccination against $M$ hyopneumoniae to demonstrate significant benefits versus the NV animals in terms of the severity of Mycoplasma-like lung lesions induced. Previously published studies performed in herds facing mixed infections with the above-mentioned pathogens showed that vaccination against PCV-2 (Raith and others 2015, Duivon and others 2016) and PRRS(V) (Revilla and others 2006), in combination with vaccination against $M$ hyopneumoniae, further reduced the prevalence of
Mycoplasma-like lung lesions at slaughter (Raith and others 2015, Duivon and others 2016), reduced mortality rates (Revilla and others 2006) and increased the ADG during the fattening period (Duivon and others 2016), when compared with $M$ hyopneumoniae vaccination alone.

The possible effect of other vaccinations applied during the same time period on $M$ hyopneumoniae vaccination or vice versa is not known. Experimental studies showed that a modified live PRRS(V) vaccine based on a US-type PRRS(V) strain (Thacker and others 2000) applied in the same time period as $M$ hyopneumoniae vaccination decreased the efficacy of $M$ hyopneumoniae vaccination. In contrast, this did not occur when a PRRS(V) vaccine based on an EU-type PRRS(V) strain was used (Drexler and others 2010). However, it is not known whether a possible interaction of $M$ hyopneumoniae vaccination and other vaccines applied at the same time period would be different when applied at weaning or shortly before weaning.

The evolution of respiratory distress in F1 is more typical of a SIV outbreak as a clear increase in the RDS was observed at 20 weeks of age and lasted for almost a week. A similar increase in coughing severity during a SIV outbreak has already been described by Berckmans and others (2015) after using microphones for monitoring respiratory distress in a Dutch herd over a three-month period. For the remaining fattening period of up to 26 weeks of age, a significantly higher overall average RDS was observed in F1 compared with F2. Thacker and others (2001) reported that concurrent infection with $M$ hyopneumoniae and SIV increased the severity and duration of EP. Van Reeth and others (1996) found that the clinical effects of PRRS(V) were exacerbated with concurrent infection with SIV. Also, it is well established that secondary infections with bacteria such as $P$ multocida and $S$ suis may enhance the severity of a SIV outbreak (Van Reeth and others 2012). Considering all the above and also the fact that there are many between-pathogen interactions which have not yet been fully elucidated, the higher RDS observed in F1 compared with F2 as well as the inconsistency in the results of group $\mathrm{V} 1$ for some of the measured parameters (such as the weight gains and ADG across the different fattening units) could possibly be attributed to the SIV outbreak. The proximity of F1 to the sow herd and the nursery unit provides a possible explanation for the origin of the SIV outbreak.

At 10 and 14 weeks of age, group V1 had significantly less animals being qPCR positive for $M$ hyopneumoniae than groups V2 and NV. Nevertheless, the impact of this lower colonisation rate on the performance and clinical parameters remains unclear. A limitation of the current study is that this lower colonisation rate together with the significantly lower average qPCR values (Log $M$ hyopneumoniae copies $/ \mathrm{ml}$ ) detected in group V1 compared with groups V2 and NV could neither be confirmed before slaughter, since there were no TBS obtained at 26 or 27 weeks of age. In a field study of Sibila and others (2007), which compared two different $M$ hyopneumoniae vaccination programmes (two vaccine doses at 1 and 3 weeks of age versus one dose at 6 weeks of age) with a control group, vaccination was related to a reduction in the number of animals found to be nPCR positive at 25 weeks of age $(37.5$ per cent and 55.8 per cent of the vaccinated animals, respectively, and 70.2 per cent of the control group). However, no quantitative method such as qPCR was used. It was concluded that a qPCR would be more useful in elucidating whether vaccination reduces the bacterial load in the upper respiratory airways during the late stages of the fattening period. Possibly, the reduced bacterial load could be associated with the shedding of less organisms. This could be interesting to investigate in a future experimental trial, where vaccinated and NV fattening pigs would be purchased from a farrow-to-finish herd and then involved in a transmission experiment using direct nose-to-nose contact.

Although this study included a high number of animals, the results should be interpreted with caution, particularly when trying to draw general conclusions from a single study. It should always be taken into account that biosecurity levels, climatic 
environment and management conditions as well as metaphylactic antimicrobial treatment and vaccination programmes differ between herds facing concurrent infections with $M$ hyopneumoniae and other respiratory pathogens. The above-mentioned parameters influence not only mixed respiratory tract infection dynamics (Bochev 2007, 2008, Thacker and Minion 2012), but also the efficacy of the vaccination protocols applied against $M$ hyopneumoniae (Maes and others 2008). Therefore, more herds with mixed respiratory disease where $M$ hyopneumoniae is involved as an important pathogen need to be investigated, in order to discover the most suitable techniques for making vaccination protocols that are tailored to the individual needs of each herd.

In conclusion, the fact that in F2 group V1 had significantly higher weight gains and ADG compared with groups V2 and NV is indicative of the potential benefits of vaccinating against $M$ hyopneumoniae three days before weaning. The SIV outbreak in F1 and the presence of other respiratory pathogens in both F1 and F2 likely influenced the performance of both vaccinated groups and highlight the difficulties of evaluating interventions in field settings. Thus, additional studies are necessary to further explore the possible impact of the process of weaning on the efficacy of vaccination against $M$ hyopneumoniae.

\section{Acknowledgements}

The authors are grateful to Sandra Willaert, Leila Vande Velde, Ria Spiessens and Els De Fré for their assistance in numerous arrangements of the trial.

Funding The study was financed by Boehringer Ingelheim but was conducted solely by the Unit Porcine Health Management at the Faculty of Veterinary Medicine of Ghent University. The authors do not have any financial or personal relationships that could inappropriately influence or bias the content of the paper.

Open Access This is an Open Access article distributed in accordance with the Creative Commons Attribution Non Commercial (CC BY-NC 4.0) license, which permits others to distribute, remix, adapt, build upon this work non-commercially, and license their derivative works on different terms, provided the original work is properly cited and the use is non-commercial. See: http://creativecommons.org/licenses/by-nc/4.0/

\section{References}

ALARCON, P., WIELAND, B., MATEUS, A. L. P. \& DEWBERRY, C. (2014) Pig farmers' perceptions, attitudes, influences and management of information in the decision-making process for disease control. Preventive Veterinary Medicine 116, 223-242

ALEXOPOULOS, C., KRITAS, S. K., PAPATSAS, I., PAPATSIROS, V. G., TASSIS, P. D. \& KYRIAKIS, S. C. (2004) Efficacy of one and two shot vaccines for the control of enzootic pneumonia (EP) in a pig unit suffering from respiratory syndrome due to EP, PRRS and PMWS. Proceedings of the 18th International Pig Veterinary Society Congress. Hamburg, Germany, June 27 to July 1, p. 449

AMASS, S. F, CLARK, L. K., VAN ALSTINE, W. G., BOWERSOCK, T. L., MURPHY, D. A., KNOX, K. E. \& ALBERGTS, S. R. (1994) Interaction of Mycoplasma hyopneumoniae and Pasteurella multocida infections in swine. Journal of the American Veterinary Medical Association 204, 102-107

ARSENAKIS, I., PANZAVOLTA, L., MICHIELS, A., DEL POZO SACRISTÁN, R., BOYEN, F., HAESEBROUCK, F. \& MAES, D. (2016) Efficacy of Mycoplasma hyopneumoniae vaccination before and at weaning against experimental challenge infection in pigs. BMC Veterinary Research 12,63

BERCKMANS, D., HEMERYCK, M., BERCKMANS, D., VRANCKEN, E. \& VAN WATERSCHOOT, T. (2015) Animal sound...talks! Real-time sound analysis for health monitoring in livestock. Proceedings of the International Symposium on Animal Environment and Welfare. Chongqing, China, October 23 to 26, pp. 215-222

BOCHEV, I. (2007) Porcine respiratory disease complex (PRDC): a review. I. etiology, epidemiology, clinical forms and pathoanatomical features. Bulgarian Journal of Veterinary Medicine 10, 131-146

BOCHEV, I. (2008) Porcine respiratory disease complex (PRDC): a review. II. diagnostics, treatment and prevention. Bulgarian Journal of Veterinary Medicine 11 219-234

BOWMAN, A. S., NOLTING, J. M., WORKMAN, J. D., COOPER, M., FISHER,

A. E., MARSH, B. \& FORSHEY, T. (2016) The inability to screen exhibition swine for influenza Avirus using body temperature. Zoonoses and Public Health 63, 34-39

CAMPBELL, J. M., CRENSHAW, J. D. \& POLO, J. (2013) The biological stress of early weaned piglets. Journal of Animal Science and Biotechnology 4,19

CHASE, C. C. L. \& LUNNEY, J. K. (2012) Immune system. In Diseases of Swine. 10th edn. Eds J. J. ZIMMERMAN, L. A. KARRIKER, A. RAMÍREZ, K. J. SCHWARTZ \& G. W. STEVENSON. Wiley-Blackwell Publishing, pp. 845-925

CIPRIÁN, A., PIJOAN, C., CRUZ, T., CAMACHO, J., TÓRTORA, J., COLMENARES, G., LÓPEZ-REVILLA, R. \& DE LA GARZA, M. (1988) Mycoplasma hyopneumoniae increases the susceptibility of pigs to experimental
Pasteurella multocida pneumonia. Canadian Journal of Veterinary Research $\mathbf{5 2}$ 434-438

DEL POZO SACRISTÁN, R., RODRÍGUEZ, A. L., SIERENS, A., VRANCKX, K BOYEN, F., DEREU, A., HAESEBROUCK, F. \& MAES, D. G. (2012) Efficacy of in-feed medication with chlortetracycline in a farrow-to-finish herd against a clinical outbreak of respiratory disease in fattening pigs. Veterinary Record 171, 645

DEL POZO SACRISTÁN, R., SIERENS, A., MARCHIORO, S. B., VANGROENWEGHE, F., JOURQUIN, J., LABARQUE, G., HAESEBROUCK, F \& MAES, D. (2014) Efficacy of early Mycoplasma hyopneumoniae vaccination against mixed respiratory disease in older fattening pigs. Veterinary Record 174, 197

DORR, P. M., BAKER, R. B., ALMOND, G. W., WAYNE, S. P. \& GEBREYES, W. A. (2007) Epidemiologic assessment of porcine circovirus type 2 coinfection with other pathogens in swine. Journal of the American Veterinary Medical Association 230, 244-250

DREXLER, C. S., WITVLIET, M. H., RAES, M., VAN DE LAAR, M., EGGEN, A. A. S. \& THACKER, E. L. (2010) Efficacy of combined porcine reproductive and respiratory syndrome virus and Mycoplasma hyopneumoniae vaccination in piglets. Veterinary Record 166, 70-74

DUIVON, D., CORRÉGÉ, I., HÉMONIC, A., RIGAUT, M. \& JOLIE, R. (2016) Combined PCV2 and M. hyopneumoniae piglet vaccination has a positive impact compared with Mhyo vaccination only, in a subclinically PCV2 infected farm. Proceedings of the Joint 24th International Pig Veterinary Society Congress and the 8th European Symposium of Porcine Health Management. Dublin, Ireland, June 7 to 10 , p. 161

GILlESPIE, J. R. \& FLANDERS, F. K. B. (2010) Swine. In Modern Livestock and Poultry Production. 8th edn. Cengage Learning, p. 440

GOODWIN, R. F. W., POMEROY, A. P. \& WHITTLESTONE, P. (1965) Production of enzootic pneumonia in pigs with a mycoplasma. The Veterinary Record $\mathbf{7 7}$ 1247-1249

HOLYOAKE, P. K. \& CALLINAN, A. P. L. (2006) How effective is Mycoplasma hyopneumoniae vaccination in pigs less than three weeks of age? Journal of Swine Health and Production 14, 189-195

JENSEN, C. S., ERSBØLL, A. K. \& NIELSEN, J. P. (2002) A meta-analysis comparing the effect of vaccines against Mycoplasma hyopneumoniae on daily weight gain in pigs. Preventive Veterinary Medicine 54, 265-278

KICK, A. R., TOMPKINS, M. B., HAMMER, J. M., ROUTH, P. A. \& ALMOND G. W. (2011) Evaluation of peripheral lymphocytes after weaning and vaccination for Mycoplasma hyopneumoniae. Research in Veterinary Science 91, e68-e72

LÓPEZ, A. \& MARTINSON, S. A. (2017) Respiratory system, mediastinum and pleurae. In Pathologic Basis of Veterinary Disease. 6th edn. Eds J. F. ZACHARY, \& M. D. MCGAVIN. Elsevier, pp. 471-561

MAES, D., VERDONCK, M., DELUYKER, H., \& DE KRUIF, A. (1996) Enzootic pneumonia in pigs. Veterinary Quarterly 18, 104-109

MAES, D., DELUYKER, H., VERDONCK, M., CASTRYCK, F., MIRY, C., LEIN, A. VRIJENS, B. \& KRUIF, A. D. (1998) The effect of vaccination against Mycoplasma hyopneumoniae in pig herds with a continuous production system. Zoonoses and Public Health 45, 495-505

MAES, D., DELUYKER, H., VERDONCK, M., CASTRYCK, F, MIRY, C., VRIJENS, B., VERBEKE, W., VIAENE, J. \& DE KRUIF, A. (1999) Effect of vaccination against Mycoplasma hyopneumoniae in pig herds with an all-in/all-out production system. Vaccine 17, 1024-1034

MAES, D., SEGALES, J., MEYNS, T., SIBILA, M., PIETERS, M. \& HAESEBROUCK, F. (2008) Control of Mycoplasma hyopneumoniae infections in pigs. Veterinary Microbiology 126, 297-309

MAROIS, C., DORY, D., FABLET, C., MADEC, F. \& KOBISCH, M. (2010) Development of a quantitative Real-Time TaqMan PCR assay for determination of the minimal dose of Mycoplasma hyopneumoniae strain 116 required to induce pneumonia in SPF pigs. Journal of Applied Microbiology 108, 1523-1533

MARTÍNEZ, J., PERIS, B., GÓMEZ, E. A. \& CORPA. J. M. (2009) The relationship between infectious and non-infectious herd factors with pneumonia at slaughter and productive parameters in fattening pigs. The Veterinary Journal 179, 240-246

MATEUSEN, B., MAES, D., VAN GOUBERGEN, M., VERDONCK, M. \& DE KRUIF, A. (2002) Effectiveness of treatment with lincomycin hydrochloride and/ or vaccination against Mycoplasma hyopneumoniae for controlling chronic respiratory disease in a herd of pigs. Veterinary Record 151, 135-140

MEYNS, T., VAN STEELANT, J., ROLLY, E., DEWULF, J., HAESEBROUCK, F. \& MAES, D. (2011) A cross-sectional study of risk factors associated with pulmonary lesions in pigs at slaughter. The Veterinary Journal 187, 388-392

MICHIELS, A., PIEPERS, S., ULENS, T, VAN RANSBEECK, N., DEL POZO SACRISTÁN, R., SIERENS, A., HAESEBROUCK, F, DEMEYER, P. \& MAES, D (2015) Impact of particulate matter and ammonia on average daily weight gain mortality and lung lesions in pigs. Preventive Veterinary Medicine 121, 99-107

MORRISON, R. B., HILLEYK, H. D. \& LEMAN, A. D. (1985a) Comparison of methods for assessing the prevalence and extend of pneumonia in market weight swine. Canadian Veterinary Journal 26, 381-384

MORRISON, R.B., PIJOAN, C., HILLEY, H.D. \& RAPP, V. (1985b) Microorganisms associated with pneumonia in slaughter weight swine. Canadian Journal of Comparative Medicine 49, 129-137

NATHUES, H., SPERGSER, J., ROSENGARTEN, R., KREIENBROCK, L. \& GROSSE BEILAGE, E. (2012) Value of the clinical examination in diagnosing enzootic pneumonia in fattening pigs. The Veterinary Journal 193, 443-447

OPRIESSNIG, T., GIMÉNEZ-LIROLA, L. G. \& HALBUR, P. G. (2011) Polymicrobial respiratory disease in pigs. Animal Health Research Reviews 12, 133-148

OPRIESSNIG, T., THACKER, E. L., YU, S., FENAUX, M., MENG, X. \& HALBUR, P. (2004) Experimental reproduction of postweaning multisystemic wasting 
syndrome in pigs by dual infection with Mycoplasma hyopneumoniae and porcine circovirus type 2. Veterinary Pathology 41, 624-640

PIÉ, S., LALLÉS, J. P., BLAZY, F, LAFFITTE, J., SEVE, B. \& OSWALD, I. P. (2004) Weaning is associated with an upregulation of expression of inflammatory cytokines in the intestine of piglets. Journal of Nutrition 134, 641-647

PILERI, E. \& MATEU, E. (2016) Review on the transmission porcine reproductive and respiratory syndrome virus between pigs and farms and impact on vaccination. Veterinary Research $\mathbf{4 7}, 108$

RAITH, J., KUCHLING, S., SCHLEICHER, C., SCHOBESBERGER, H. \& KÖFER J. (2015) Influence of porcine circovirus type 2 vaccination on the probability and severity of pneumonia detected postmortem. Veterinary Record 176, 124

REVILLA, E., ADAM, M., SALLERAS, J. M. \& RUBIO, S. (2006) PRDC control strategy through PRRSV and Mycoplasma hyopneumoniae vaccination in Spain. A field case. Proceedings of the 19th International Pig Veterinary Society Congress. Copenhagen, Denmark, July 16 to 19, p. 297

SEGALÉS, J., ALLAN, G. M. \& DOMINGO, M. (2012) Porcine circoviruses. In Diseases of Swine. 10th edn. Eds J. J. ZIMMERMAN, L. A. KARRIKER, A. RAMÍREZ, K. J. SCHWARTZ \& G. W. STEVENSON. Wiley-Blackwell Publishing, pp. 1470-1522

SIBILA, M., CALSAMIGLIA, M., VIDAL, D., BADIELLA, L., ALDAZ, A. \& JENSEN, J. C. (2004) Dynamics of Mycoplasma hyopneumoniae infection in 12 farms with different production systems. Canadian Journal of Veterinary Research 68, 12-18

SIBILA, M., NOFRARÍAS, M., LÓPEZ-SORIA, S., SEGALÉS, J., VALERO, O. ESPINAL, A. \& CALSAMIGLIA, M. (2007) Chronological study of Mycoplasma hyopneumoniae infection, seroconversion and associated lung lesions in vaccinated and non-vaccinated pigs. Veterinary Microbiology 122, 97-107

SORENSEN, V., JORSAL, S. E. \& MOUSING, J. (2006) Diseases of the respiratory system. In Diseases of Swine. 9th edn. Eds B. E. STRAW, J. J. ZIMMERMAN, S. D'ALLAIRE \& D. J. TAYLOR. Blackwell Publishing, pp 149-179

STÄRK, K. D., NICOLET, J. \& FREY, J. (1998) Detection of Mycoplasma hyopneumoniae by air sampling with a nested PCR assay. Applied and Environmental Microbiology 64, 543-548

THACKER, E. L., HALBUR, P. G., ROSS, R. F. THANAWONGUWECH, R. \& THACKER, B. J. (1999) Mycoplasma hyopneumoniae potentiation of porcine reproductive and respiratory syndrome virus-induced pneumonia. Journal of Clinical Microbiology 37, 620-627
THACKER, E. L. \& MINION, C. F. (2012) Mycoplasmosis. In Diseases of Swine 10th edn. Eds J. J. ZIMMERMAN, L. A. KARRIKER, A. RAMÍREZ, K. J. SCHWARTZ \& G. W. STEVENSON. Wiley-Blackwell Publishing, pp. 2850-2923

THACKER, E. L., THACKER, B. D. \& JANKE, B. H. (2001) Interaction between Mycoplasma hyopneumoniae and swine influenza virus. Journal of Clinical Microbiology 39, 2525-2530

THACKER, E. L., THACKER, B. J., YOUNG, T. F \& HALBUR, P. G. (2000) Effect of vaccination on the potentiation of porcine reproductive and respiratory syndrome virus (PRRSV)-induced pneumonia by Mycoplasma hyopneumoniae. Vaccine 18, 1244-1252

VAN ALSTINE, W. G. (2012) Respiratory system. In Diseases of Swine. 10th edn Eds J. J. ZIMMERMAN, L. A. KARRIKER, A. RAMÍREZ, K. J. SCHWARTZ \& G. W. STEVENSON. Wiley-Blackwell Publishing, pp 1273-1331

VANGROENWEGHE, F A. C. J., LABARQUE, G. G., PIEPERS, S, STRUTZBERG-MINDER, K. \& MAES, D. (2015) Mycoplasma hyopneumoniae infections in peri-weaned and post-weaned pigs in Belgium and The Netherlands: prevalence and associations with climatic conditions. The Veterinary Journal 205, 93-97

VAN REETH, K., NAUWYNCK, H. \& PENSAERT, M. (1996) Dual infections of feeder pigs with porcine reproductive and respiratory syndrome virus followed by porcine respiratory coronavirus or swine influenza virus: a clinical and virological study. Veterinary Microbiology 48, 325-335

VAN REETH, K., BROWN, I. H. \& OLSEN, C. W. (2012) Influenza virus. In Diseases of Swine. 10th edn. Eds J. J. ZIMMERMAN, L. A. KARRIKER, A. RAMÍREZ, K. J. SCHWARTZ \& G. W. STEVENSON. Wiley-Blackwell Publishing, pp. 2036-2095

WILSON, S., VAN BRUSSEL, L., SAUNDERS, G., TAYLOR, L., ZIMMERMANN L., HEINRITZI, K., RITZMANN, M., BANHOLZER, E. \& EDDICKS, M. (2012) Vaccination of piglets at 1 week of age with an inactivated Mycoplasma hyopneumoniae vaccine reduces lung lesions and improves average daily gain in body weight. Vaccine 30, 7625-7629

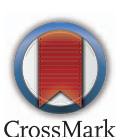




\section{Veterinary Mycoplasma hyopneumoniae vaccination at or shortly before weaning under field conditions: a randomised efficacy trial}

I. Arsenakis, A. Michiels, R. Del Pozo Sacristán, F. Boyen, F. Haesebrouck and D. Maes

Veterinary Record 2017 181: 19 originally published online June 10, 2017 doi: 10.1136/vr.104075

Updated information and services can be found at: http://veterinaryrecord.bmj.com/content/181/1/19

\begin{tabular}{|c|c|}
\hline & These include: \\
\hline References & $\begin{array}{l}\text { This article cites } 42 \text { articles, } 9 \text { of which you can access for free at: } \\
\text { http://veterinaryrecord.bmj.com/content/181/1/19\#BIBL }\end{array}$ \\
\hline Open Access & $\begin{array}{l}\text { This is an Open Access article distributed in accordance with the Creative } \\
\text { Commons Attribution Non Commercial (CC BY-NC 4.0) license, which } \\
\text { permits others to distribute, remix, adapt, build upon this work } \\
\text { non-commercially, and license their derivative works on different terms, } \\
\text { provided the original work is properly cited and the use is } \\
\text { non-commercial. See: http://creativecommons.org/licenses/by-nc/4.0/ }\end{array}$ \\
\hline $\begin{array}{c}\text { Email alerting } \\
\text { service }\end{array}$ & $\begin{array}{l}\text { Receive free email alerts when new articles cite this article. Sign up in the } \\
\text { box at the top right corner of the online article. }\end{array}$ \\
\hline $\begin{array}{r}\text { Topic } \\
\text { Collections }\end{array}$ & $\begin{array}{l}\text { Articles on similar topics can be found in the following collections } \\
\text { Open access (112) }\end{array}$ \\
\hline
\end{tabular}

\section{Notes}

To request permissions go to:

http://group.bmj.com/group/rights-licensing/permissions

To order reprints go to:

http://journals.bmj.com/cgi/reprintform

To subscribe to BMJ go to:

http://group.bmj.com/subscribe/ 